\title{
Editorial: Reconstruction of Brains and Journals
}

This issue begins a new incarnation of the Journal of Neural Transplantation and Plasticity (JNTP). New journals, new editorships, and major changes are often the occasion for the writing of editorials; this time, it is a new editorship and a clarification of purpose. With this issue, JNTP is re-dedicated to the publication of highquality studies of neural transplantation and plasticity. JNTP will aim to become a leading journal in the field by maintaining high standards of quality and a clearly-focused mission.

The editors and publisher especially wish to thank Drs. Uri Yinon and Paul Sanberg for their prior service as editor-in-chief and interim editor respectively. Paul Sanberg has agreed to continue to serve as a member of the editorial board. Through their efforts, JNTP has become established and developed a record of consistent publication of quality papers.

\section{THE MISSION OF JNTP}

The mission of JNTP is to serve as a forum for studies on manipulating, promoting, or guiding neural plasticity. Neural transplantation, at the moment, accounts for a large part of this literature. Due to recent advances in molecular biology, it appears likely that intervention in brain circuitry through administration or manipulation of growth factors will in the near future at least equal transplantation as a major area of research. Other similarly promising methods of manipulating neural plasticity include, for example, altering the substrate for neural growth $/ 2,11,50 /$ implantation of encapsulated cells $/ 1,70 /$ and polymers or gel matrices $/ 71 /$, use of chronic drug-releasing polymers $/ 3,23,40 /$, and genetic manipulation of neuronal cells in situ /24/. The niche for JNTP is to communicate studies of neural transplantation as well as neural plasticity, especially studies of neural plasticity that are relevant to experimental manipulation. This would include studies in areas such as effects of trophic factors, production of trophic or growthinhibitory factors by brain $/ 41 /$, recovery of func- tion after lesions, including studies of reorganization of neural circuits $/ 51 /$, effects of behavioral training/66, 68/ and drug administration $/ 6,12,28 /$, survival or replacement of neuronal circuits, and enhancement or guiding of collateral sprouting or axonal regeneration, or studies which shed light on possibilities for such techniques.

In addition to its use as a means of manipulating brain function, neural transplantation has important applications as a basic research tool. The functional role of circuits in the brain has for the most part been defined by the consequences of their absence, following either experimental or accidental lesions. Neural transplantation is unique as a research tool in that scientists can begin to discern the functional contributions of newly constructed or permanently modified neural circuits. When used as a basic research tool, transplantation can help to explore the role of neuronal circuits by allowing for both removal (lesioning) and replacement (transplantation). Neural transplantation also serves as a method with which to study brain development, and can be a valuable tool for studying the processes of neuronal migration and segregation /59/ and the formation of synaptic connections. Studies on these topics would also be within the scope of JNTP.

\section{POTENTIAL APPLICATIONS IN MODELS OF DISEASE}

There is, of course, a hope that transplantation or techniques for manipulation of neural plasticity which have been developed in animal models will ultimately be useful to treat degenerative disease or injury in humans. For the most part, a rational and systematic development of appropriate animal models, and subsequently potential modes of therapy, for any disease requires that first the neuronal mechanisms and circuits which are involved be understood at least to some degree. Secondly, the relationships between these circuits and the disease itself must be found. Usually, this understanding can only be gained by basic studies of neuronal circuits in animals, followed by post- 
mortem biochemical studies, histopathology, or potentially neural imaging studies of these circuits in living subjects. Finally, once a picture of the disease process has developed, clinical manipulation can be planned rationally. When clinical intervention is considered, ideally, transplantation will in time be only one of an array of methods which can be used to effect localized changes in the functioning of neuronal circuits. Intervention to alter neuronal plasticity might take many forms, including pharmacological treatments, localized administration of support matrices or growth factors, genetic manipulations, or behavioral training $120 \%$.

Possibly the most direct form of manipulation of neural plasticity is to promote endogenous neurons to grow or form new connections. It may be possible to enhance the plasticity of mature neurons by genetic reprogramming, but it may also be possible to accomplish the same goal more simply by the administration of exogenous substances, generically "growth factors". The prototype growth factor, nerve growth factor (NGF), has been known and studied for decades $/ 33 /$. NGF has a specific influence on peripheral sympathetic and sensory neurons and on central cholinergic neurons. Until recently, there have been relatively few studies of the effects of administration of NGF. In the past few years, however, possibilities for the use of NGF administration to enhance functional recovery from lesions, sparing of neurons following axotomy, and prevention of degeneration have begun to appear $/ 29,34 /$. The most likely avenues for potential therapeutic effects of NGF are in peripheral neuropathy and Alzheimer's disease. Advances in growth factor identification through molecular biology have led to the clarification of what has long been suspected, that an entire class of neurotrophins, growth factors with varying specificity for different neuronal populations, exists. In fact, numerous substances belonging to a variety of classes of proteins have neurotrophic activity under various circumstances. Availability of these proteins in pure form has greatly facilitated studies of effects of their administration. Neurotrophic factors can be employed in a variety of strategies; they can be administered directly to the brain, or peripherally in models of peripheral neuropathy, or they can perhaps be used to enhance the effects of neuronal tissue transplants. There are complex issues associated with methods of administration of proteins to living organisms. Possibilities for administration include chronic injection, administration through various kinds of chronic infusion pumps, incorporation into gels or slow-release matrices, and elicitation of expression of growth factors by endogenous $/ 24 /$ or transplanted / $14,54 /$ cells.

The second major form of manipulation of neural plasticity is neural transplantation. The "prototype" disorder for neural transplantation, Parkinson's disease, is in that position because the nature of the affected neuronal circuits is largely known. Conceptually, the goals of transplantation research in Parkinson's disease, both clinically and in animal models, are clear: replacement of the dopaminergic afferentation of the neostriatum. Most of the efforts in this area have been concentrated on three tissue sources, each with quite different origins: These include: (a) transplantation of fetal substantia nigra into the striatum or lateral ventricles $/ 4,17,19,65 /$, (b) the use of adrenal medulla as an alternate source of catecholamine-producing cells $/ 21,63$ / with possible trophic effects as well $/ 5,45,48 /$, and (c) the use of catecholaminergic cell lines $/ 1,15,30 \%$. There have been a substantial number of human clinical trials of both adrenal medulla and substantia nigra transplantation $/ 16,27,35-37 /$. Some relatively modest improvements have been observed in most of the clinical trials. Limitations of clinical trials of adrenal medulla grafts have included a gradual loss of improvements $/ 43 /$, a high frequency of side-effects including death, as well as psychological disturbances and dementia /38, 44/, and inconsistent graft survival $/ 47 /$. For clinical trials of embryonic SN grafts, the results are generally promising, especially regarding the apparently smaller frequency of side effects. Nevertheless, the degree of improvement seen in human subjects after SN grafts is generally modest, and so far not qualitatively greater than the effects of adrenal medulla grafts. Improvements in the performance of transplantation procedures may arise, for example, from advances in surgical technique $/ 9,10$ / or improvement of the performance of grafts through the administration of growth factors $/ 62 /$ or co-transplantation of tissues 
which may secrete growth factors $/ 8,22,32,67 /$. Efforts to develop new sources of dopamine-producing cells, through immortalization $/ 7,25,55 /$ or other genetic alteration of cells $/ 15,30 /$, derivation of cells from tumors $/ 39 /$, and perhaps the use of cells generated from the brain through other techniques $/ 49,52,53 /$ are also guided by the same goal, of finding improved methods of replacing the dopaminergic system.

Additional possibilities for application of transplantation and administration of growth factors in models of disease are likely to emerge over the course of time. For neural transplantation, two other notable possibilities have recently emerged, in particular chronic pain syndromes $156,57 /$ and Huntington's disease $/ 26,31,64,69 /$. Interesting possibilities have also been raised in connection with application of transplantation to more complex animals models /42/. Although possibilities for applications to other clinical disorders are more remote, research is being conducted in a number of different areas. For example, studies on transplantation in the visual system and in models of cortical injury are represented by papers in this and other recent issues of JNTP $/ 13,46,58,60 /$. Peripheral neuropathies are at present the most immediate candidates for clinical application of growth factors for similar reasons, e.g., because the goals of potential therapies are clear. Such a clear picture is available for few other disorders. Nevertheless, there are other potential avenues for clinical applications. Clinical trials of NGF administration in Alzheimer's disease are currently being conducted. It is probable, however, that some neuronal degenerative disorders will have properties which are not amenable to manipulation according to any existing concept. For these, the properties of the disorder, once found, may indicate new therapeutic possibilities. It is entirely possible that techniques for manipulating brain plasticity, in any form, will find application for diseases (e.g., schizophrenia) which are as yet not at all understood.

The issues of application of therapy to humans are complex and have not been considered systematically $/ 18,61 /$. It is generally acknowledged that degree of risk and invasiveness bears a direct relationship to the amount of justification and degree of confidence in the procedure which should be required. For example, there are certainly some avenues for manipulation that can be employed following brain injury, even without any understanding of the neural circuits involved. The most notable of these is behavioral training. It is well established that behavioral training can do a great deal to aid recovery following CNS damage $/ 66 /$,yet the reasons why the training works and the nature of the brain damage to be treated are not yet understood. Where more complex or invasive procedures are required, a more thorough rationale is certainly needed. As yet there are no systematic procedures for considering rationales for clinical procedures such as brain tissue transplantation. JNTP hopes to become a major forum for communication of information related to manipulation of neural plasticity through transplantation and other techniques. This will include, in addition to original research papers, scholarly discussion of issues related to the applicability and justification for potentially invasive techniques.

\section{QUALITY STANDARDS FOR JNTP}

JNTP will endeavor to publish research of high quality, specifically in terms of methodology, experimental design, clarity of logic, careful formulation of conclusions, appropriate statistics, and research fundamentals. Issues such as coding of samples, blind testing, random assignment of animals to groups, use of appropriate control groups, and quantification of histological and histochemical data where appropriate will be especially emphasized. Editorial board members and referees will be asked to pay particular attention to these factors.

To give some concrete examples of what will be asked of the referees: For behavioral studies, appropriate control groups will be expected and experimental designs will be examined for the ability to support the stated conclusions. Studies which are based on changes in histological and histochemical parameters induced by experimental manipulations (as opposed to descriptive histology) will usually be expected to provide appropriate quantitative data or other forms of objective data presentation. Referees will be asked to assess whether these data were collected in con- 
trolled and carefully designed experiments. Conclusions will be examined to determine whether they can be supported by the choice of control groups and experimental design. For clinical studies, where it is often impossible to employ controls or large numbers of subjects, experimental design issues such as baseline testing, frequent assessments, quantitative measurements of outcome, and attention to problems such as separate testing during "on" and "off" phases (in Parkinson's disease) are even more important. In other cases, such as studies of primates, where practical realities limit the experimental design, authors will be expected to point out these limitations in their conclusions.

Although manuscripts describing new and exciting findings are certainly desired, these will be published only if they also meet similar criteria of quality. In fact, specialized studies which extend upon, clarify, or refute an earlier study are especially sought after as candidates for publication in JNTP. It is also important to note that quality is not necessarily synonymous with completeness, length, or even thoroughness. Short papers, and brief communications are solicited as well. Papers that carefully address a single, restricted aspect of a problem are encouraged provided that, within their own limits, the work presented is of similar high quality. Technical reports and papers describing new methods are also encouraged.

The journal is interested in publishing scholarly reviews, commentaries, and letters questioning issues related to neural transplantation and methods of manipulating neural plasticity. Commentaries and letters which question conclusions of earlier studies or research areas, raise issues of experimental design, either advocate or question opportunities for human application, or address controversial issues in neural transplantation and plasticity are solicited. JNTP is particularly interested in reviews which examine the conclusions and designs of earlier studies in detail. In general, review papers should offer new conclusions, integration, or re-interpretations of other studies. Reviews which simply abstract or enumerate previous experiments are not desired. Reviews may be submitted without prior arrangement with the editor-in-chief, although prior consultation may increase the likelihood of acceptance.
The field of neural tissue transplantation and manipulation of neuronal plasticity has become one of the central specialties in neuroscience. JNTP aims to become a first choice forum for communication of research and controversy in this area.

William J. Freed

and

The Editorial Board of JOURNAL OF NEURAL TRANSPLANTATION AND PLASTICITY

\section{REFERENCES}

1. Aebischer P, Tresco PA, Winn SR, Greene LA, Jaeger CB. Long-term cross-species brain transplantation of a polymer-encapsulated dopamine-secreting cell line. Exp Neurol 1991; 111: 269-275.

2. Bartsch S, Bartsch U, Dorries U, Faissner A, Weller A, Ekblom P, Schachner M. Expression of tenascin in the developing and adult cerebellar cortex. J Neurosci 1992; 12: 736-749.

3. Becker JB, Robinson TE, Barton P, Sintov A, Siden R, Levy RJ. Sustained behavioral recovery from unilateral nigrostriatal damage produced by the controlled release of dopamine from a silicone polymer pellet placed into the denervated striatum. Brain Res 1990; 508: 60-64.

4. Bjorklund $A$, Lindvall $O$, Isacson $O$, Brundin $P$, Wictorin K, Strecker RE, Clarke DJ, Dunnett SB. Mechanisms of action of intracerebral neural implants: studies on nigral and striatal grafts to the lesioned striatum. Trends Neurosci 1987; 10: 509-516.

5. Bohn MC, Marciano F, Cupit L, Gash DM. Adrenal medullary grafts promote recovery of striatal dopaminergic fibers in MPTP treated mice. Science 1987; 237: 913-916.

6. Boyeson MG, Feeney DM. Intraventricular norepinephrine facilitates motor recovery following sensorimotor cortex injury. Pharmacol Biochem Behav 1990; 35: 497-501.

7. Bredesen DE, Hisanaga K, Sharp FR. Neural transplantation using temperature-sensitive immortalized neural cells: A preliminary report. Ann Neurol 1990; 27: 205-207.

8. Collier TJ, Springer JE. Co-grafts of embryonic dopamine neurons and adult sciatic nerve into the denervated striatum enhance behavioral and morphological recovery in rats. Exp Neurol 1991; 114: 343-350.

9. Dubach $\mathbf{M}$. Viable adrenal medullary transplants in non-human primates: Increasing the number of grafts. J Neur Transplant Plast (this issue). 
10. Dubach M. Behavioral effects of adrenal medullary transplants in non-human primates. J Neur Transplant Plast (this issue).

11. Edelman GM. Cell adhesion molecules in the regulation of animal form and tissue pattern. Annual Rev Cell Biol 1984; 281-316.

12. Emerich DF. Behavioral effects of gangliosides: Anatomical considerations. J Neur Transplant Plast 1992; 3: 1-19.

13. Epstein LG, Cvetkovich TA, Lazar E, Dehlinger K, Dzenko K, del Cerro C, del Cerro M. Successful xenografts of second trimester human fetal brain retinal tissue in the anterior chamber of the eye of adult immunosuppressed rats. J Neur Transplant Plast (this issue).

14. Ernfors $P$, Ebendal T, Olson L, Mouton P, Stromberg I, Persson H. A cell line producing recombinant nerve growth factor evokes growth responses in intrinsic and grafted central cholinergic neurons. Proc Natl Acad Sci USA 1989; 86: 4756-4760.

15. Fisher LJ, Jinnah HA, Kale LC, Higgins GA, Gage FH. Survival and function of intrastriatal grafts of primary fibroblasts genetically modified to produce L-DOPA. Neuron 1991; 6: 371-380.

16. Freed CR, Breeze RE, Rosenberg NL, Schneck SA, Well TH, Barrett JN, Grafton ST, Huang SC, Eidelberg D, Rottenberg DA. Transplantation of human fetal dopamine cells for Parkinson's disease: Results at 1 year. Arch Neurol 1990; 47: 505-512.

17. Freed WJ. Functional brain tissue transplantation: reversal of lesion-induced rotation by intraventricular substantia nigra and adrenal medulla grafts with a note on intracranial retinal grafts. Biol Psychiatry 1983; 18: 1205-1267.

18. Freed WJ. Editorial: Brain tissue grafting and human applications. J Neurosurgical Anesthesiol 1991; 3: 167-169.

19. Freed WJ. Substantia nigra grafts and Parkinson's disease: From animal experiments to human therapeutic trials. Restorative Neurol Neurosci 1991; 3: 109-134.

20. Freed WJ, de Medinaceli L, Wyatt RJ. Promoting functional plasticity in the damaged nervous system. Science 1985; 227: 1544-1552.

21. Freed WJ, Poltorak M, Becker JB. Intracerebral adrenal medulla grafts: A review. Exp Neurol 1990; 110: 139-166.

22. Freed WJ, Willingham G, Heim RC. Effects of adrenal medulla and sciatic nerve co-grafts in rats with unilateral substantia nigra lesions. J Neur Transplant Plast (this issue).

23. Freese A, Sabel BA, Saltzman WM, During MJ, Langer R. Controlled release of dopamine from a polymeric brain implant: In vitro characterization. Exp Neurol 1989; 103: 234-238.

24. Geller AI, Keyomarski K, Bryan J, Pardee AB. An efficient deletion mutant packaging system for defective HSV-1 vectors: Potential applications to neuronal physiology and human gene therapy. Proc Natl Acad Sci USA 1990; 87: 8950-8954.

25. Geller HM, Quinones-Jenab V, Poltorak M, Freed WJ. Applications of immortalized cells in basic and clinical neurology. J Cell Biochem 1991; 45: 279-283.

26. Giordano M, Ford LM, Shipley MT, Sanberg PR. Neural grafts and pharmacological intervention in a model of Huntington's disease. Brain Res Bull 1990; 25: 453-465.

27. Goetz CG, Olanow CW, Koller WC, Penn RD, Cahill D, Morantz R, Stebbins G, Tanner CM, Klawans HL, Shannon KM, Comella CL, Witt T, Cox C, Waxman M, Gauger L. Multicenter study of autologous adrenal medullary transplantation of the corpus striatum in patients with advanced Parkinson's disease. N Engl J Med 1989; 320: 337-341.

28. Goldstein LB, Coviello A, Miller GD, Davis JN. Norepinephrine depletion impairs motor recovery following sensorimotor cortex injury in the rat. Restor Neurol Neurosci 1991; 3: 41-47.

29. Hefti F, Hartikka J, Knusel B. Function of neurotrophic factors in the adult and aging brain and their possible use in the treatment of neurodegenerative diseases. Neurobiol Aging 1989; 10: 515-533.

30. Horrellou P, Brundin P, Kalen P, Mallet J, Bjorklund A. In vivo release of DOPA and dopamine from genetically engineered cells grafted to the denervated rat striatum. Neuron 1990; 5: 393-402.

31. Isacson $\mathrm{O}$, Hantraye $\mathrm{P}$, Maziere $M$, Sofroniew MV, Riche D. Apomorphine-induced dyskinesias after excitotoxic caudate-putamen lesions and the effects of neural transplantation in non-human primates. In: Dunnett SB, Richards S-J, eds, Neural Transplantation: From Molecular Basis to Clinical Applications. Elsevier, Amsterdam: Prog Brain Res 1990; 82: 523533.

32. Kordower JH, Fiandaca MS, Notter MFD, Hansen JT, Gash DM. Peripheral nerve provides NGF-like trophic support for grafted rhesus adrenal chromaffin cells. J Neurosurg 1990; 73: 418-428.

33. Levi-Montalcini $\mathbf{R}$. The nerve growth factor: Thirtyfive years later. EMBO J 1987; 6: 1145-1154.

34. Lindsay RM. Nerve growth factors (NGF, BDNF) enhance axonal regeneration but are not required for survival of adult sensory neurons. J Neurosci 1988; 8: 2394-2405.

35. Lindvall $\mathbf{P}$, Brundin $\mathbf{P}$, Widner $\mathbf{H}$, Rehncrona $S$, Gustavii B, Frackowiak R, Leenders KL, Sawle G, Rothwell JC, Marsden CD, Bjorklund A. Grafts of fetal dopamine neurons survive and improve motor function in Parkinson's disease. Science 1990; 247: 574-577.

36. Madrazo I, Drucker-Colin R, Diaz V, Martinez-Marta J, Torres C, Becerril JJ. Open microsurgical autograft of adrenal medulla to the right caudate nucleus in Parkinson's disease: A report of two cases. N Engl J Med 1987; 316: 831-834.

37. Madrazo I, Franco-Bourland R, Aguilera M, Ostrosky-Solis F, Madrazo M, Cuevas C, Castrejon H, 
Guizar-Zahagun G, Magallon E. Autologous adrenal medullary, fetal mesencephalic, and fetal adrenal brain transplantation in Parkinson's disease: A longterm postoperative follow-up. J Neur Transplant Plast 1991; 2: 157-164.

38. Madrazo I, Franco-Bourland R, Ostrosky-Solis F, Aguilera A, Cuevas C, Castrejon H, Guizar G, Magallon E. Dementia following brain grafting. Transplantation 1990; 49: 1026-1027.

39. Manaster JS, Feuerman T, Reynolds CP, Markham $\mathrm{CH}$. Transplantation of human neuroblastoma cells, catecholaminergic and non-catecholaminergic: Effects on rotational behavior in Parkinson's rat model. J Neur Transplant Plast (this issue).

40. McRae A, Hjorth S, Mason DW, Dillon L, Tise TR. Microencapsulated dopamine (DA)-induced restitution of function in 6-OHDA-denervated rat striatum in vivo: Comparison between two microsphere excipients. J Neur Transplant Plast 1991; 2: 165-173.

41. Nieto-Sampedro $M$, Whittemore SR, Needels DL, Larson J, Cotman CW. The survival of brain transplants is enhanced by extracts from injured brain. Proc Natl Acad Sci USA 1984; 81: 6250-6254.

42. Nilsson OG, Brundin P, Bjorklund A. Amelioration of spatial memory impairment by intrahippocampal grafts of mixed septal and raphe tissue in rats with combined cholinergic and serotonergic denervation of the forebrain. Brain Res 1990; 515: 193-206.

43. Olanow CW, Koller W, Goetz CG, Stebbins GT, Cahill DW, Gauger LL, Morantz R, Penn RD, Tanner CM, Klawans JL, Shannon KM, Comella CL, Witt T. Autologous transplantation of adrenal medulla in Parkinson's disease: 18 month results. Arch Neurol 1990; 47: 1286-1289.

44. Ostrosky-Solis F, Quintanar L, Madrazo I, DruckerColin R, Franco-Bourland R, Leon-Meza V. Neuropsychological effects of brain autograft of adrenal medullary tissue for the treatment of Parkinson's disease. Neurology 1988; 38: 1442-1450.

45. Otto D, Unsicker K. Basic FGF reverses chemical and morphological deficits in the nigrostriatal system of MPTP treated mice. J Neurosci 1990; 10: 1912-1921.

46. Pedersen EB, O'Keefe JA, Handa RJ, Castro AJ. Estrogen receptors are present in neocortical transplants. J Neur Transplant Plast (this issue).

47. Peterson DI, Price ML, Small CS. Autopsy findings in a patient who had an adrenal-to-brain transplant for Parkinson's disease. Neurology 1989; 39: 235-238.

48. Poltorak M, Freed WJ. Cell adhesion molecules in adrenal medulla grafts: Enhancement of chromaffin cell $\mathrm{L1} / \mathrm{Mg}$-CAM expression and reorganization of extracellular matrix following transplantation. Exp Neurol 1990; 110: 73-85.

49. Poltorak M, Isono M, Freed WJ, Ronnett GV, Snyder SH. Human cortical neuronal cell line (HCN-1): Further in vitro characterization and suitability for brain transplantation. Cell Transplantation 1992; 1: 3-15.

50. Poltorak M, Shimoda K, Freed WJ. L1 substrate enhances outgrowth of tyrosine hydroxylase im- munoreactive neurites in mesencephalic cell culture. Exp Neurol (in press).

51. Pons TP, Garraghty PE, Ommaya AK, Kaas JH, Taub E, Mishkin M. Massive cortical reorganization after sensory deafferentation in adult macaques. Science 1991; 252: 1857-1860.

52. Reynolds BA, Weiss S. Generation of neurons and astrocytes from isolated cells of the adult mammalian central nervous system. Science 1992; 255: 1707-1710.

53. Ronnett GV, Hester LD, Nye JS, Connors K, Snyder SH. Human cortical neuronal cell line: Establishment from a patient with unilateral megalencephaly. Science 1990; 248: 603-605.

54. Rosenberg MB, Friedmann $T$, Robertson RC, Tuszynski M, Wolff JA, Breakefield XO, Gage F. Grafting genetically modified cells to the damaged brain: restorative effects of NGF expression. Science 1988; 242: 1575-1578.

55. Ryder EF, Snyder EY, Cepko CL. Establishment and characterization of multipotent neural cell lines using retrovirus vector-mediated oncogene transfer. J Neurobiol 1990; 21: 356-375.

56. Sagen J, Pappas GD, Perlow MJ. Alteration in nociception following adrenal medullary transplants into the rat periaqueductal gray. Exp Brain Res 1987; 67: 373-379.

57. Sagen J, Wang H, Pappas GD. Adrenal medullary implants in the rat spinal cord reduce nociception in a chronic pain model. Pain 1990; 42: 69-79.

58. Sandor R, Gonzalez MF, Moseley M, Sharp FR. Motor deficits are produced by removing some cortical transplants grafted into injured sensorimotor cortex of neonatal rats. J Neur Transplant Plast 1991; 2: 221-233.

59. Snyder EY, Deitcher DL, Walsh C, Arnold-Aldea S, Hartwieg EA, Cepko CL. Multipotent neural cell lines can engraft and participate in development of mouse cerebellum. Cell 1992; 68: 33-51.

60. Soares H, McIntosh TK. Fetal cortical transplants in adult rats subjected to experimental brain injury. $J$ Neur Transplant Plast 1991; 2: 207-220.

61. Stein DG. Fetal brain tissue grafting as therapy for brain dysfunctions: Unanswered questions, unknown factors, and practical concerns. J Neurosurgical Anesthesiol 1991; 3: 170-189.

62. Stromberg I, Herrera-Marschitz M, Ungerstedt U, Ebendal T, Olson L. Chronic implants of chromaffin tissue into the dopamine-denervated rat striatum. Effects of NGF on graft survival, fiber growth, and rotational behavior. Exp Brain Res 1985; 60: 335-349.

63. Takashima H, Poltorak M, Becker JB, Freed WJ. Effects of adrenal medulla grafts on plasma catecholamines and rotational behavior. Exp Neurol (in press).

64. Tandon PN, Kumar VM, Verma S, Gopinath G, Shetty AK. Fetal brain transplantation in kainic acid lesioned caudate nucleus of adult rats. J Neur Transplant Plast (this issue). 
65. Taylor JR, Elsworth JD, Roth RH, Sladek JR Jr, Collier TJ, Redmond DE Jr. Grafting of fetal substantia nigra to striatum reverses behavioral deficits induced by MPTP in primates: A comparison with other types of grafts as controls. Exp Brain Res 1991; 85: 335-348.

66. Teuber H-L. Recovery of function after lesions of the central nervous system: history and prospects. Neurosci Res Prog Bull 1974; 197-211.

67. van Horne CG, Stromberg I, Young D, Olson L, Hoffer B. Functional enhancement of intrastriatal dopamine-containing grafts by the co-transplantation of sciatic nerve tissue in 6-hydroxydopamine-lesioned rats. Exp Neurol 1991; 113: 143-154.

68. Whishaw IQ, Zaborowski J-D, Kolb B. Postsurgical enrichment aids adult hemidecorticate rats on a spa- tial navigation task. Behav Neural Biol 1984; 42: 183190.

69. Wictorin K, Simerly RB, Isacson O, Swanson LW, Bjorklund A. Connectivity of striatal grafts implanted into the ibotenic acid-lesioned striatum. III. Efferent projecting neurons and their relation to host afferents within the grafts. Neuroscience 1989; 30: 313-330.

70. Winn SR, Tresco PA, Zielkinski B, Sagen J, Aebischer P. Microencapsulated bovine chromaffin cells in vitro: Effect of density and coseeding with a NGF-releasing cell line. J Neur Transplant Plast (this issue).

71. Woerly S, Lavallee $C$, Marchand $R$. Intracerebral implantation of ionic synthetic hydrogels: effect of polar substrata on astrocytosis and axons. J Neur Transplant Plast 1992; 3: 21-34. 

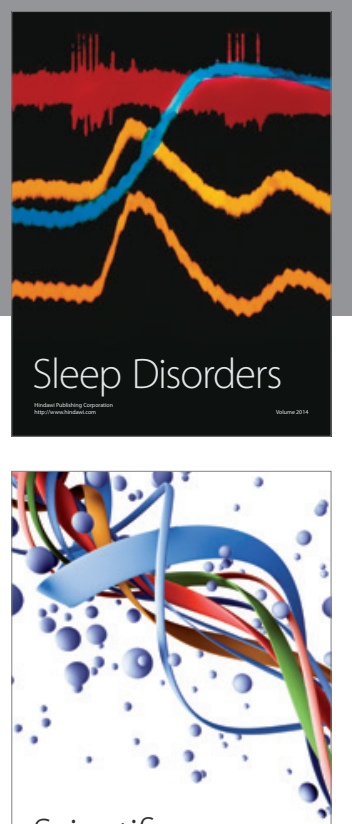

Scientifica
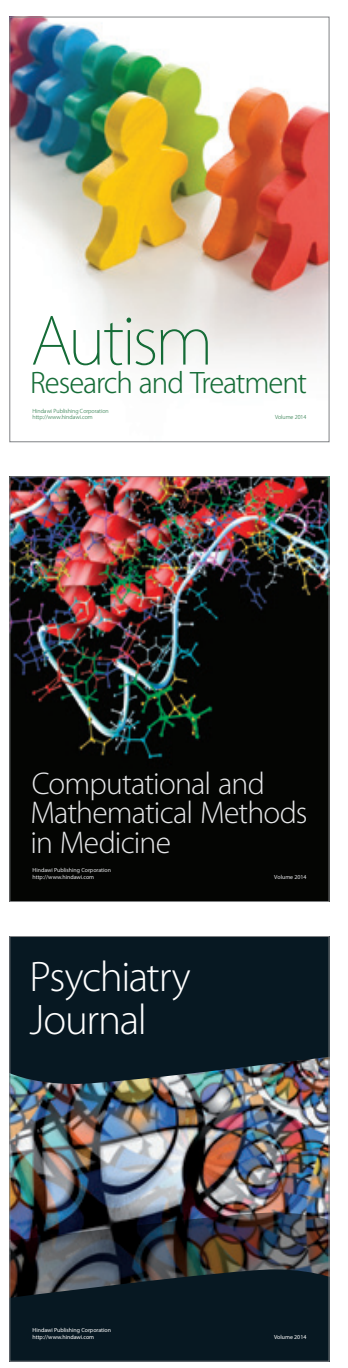
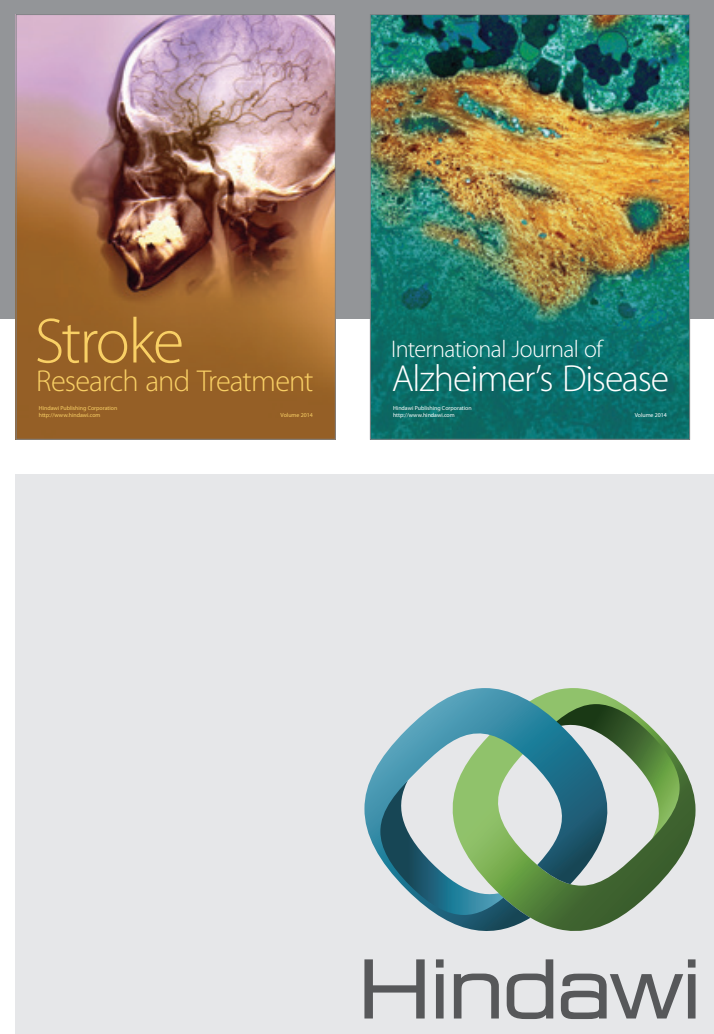

Submit your manuscripts at

http://www.hindawi.com
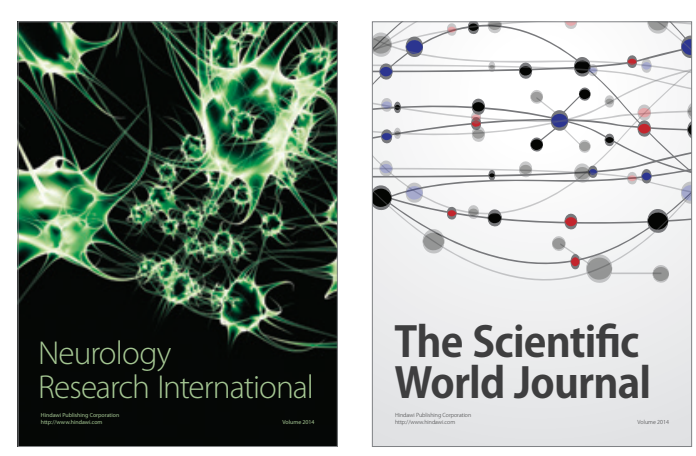

The Scientific World Journal

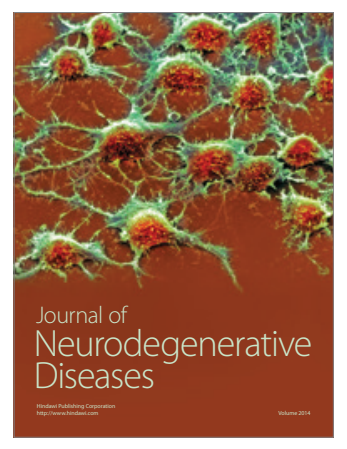

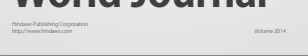

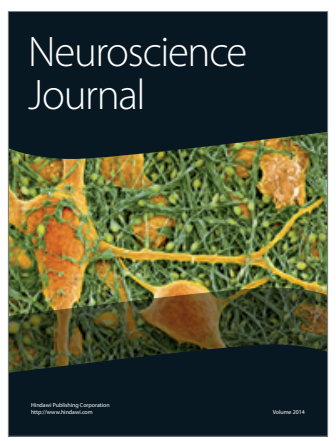

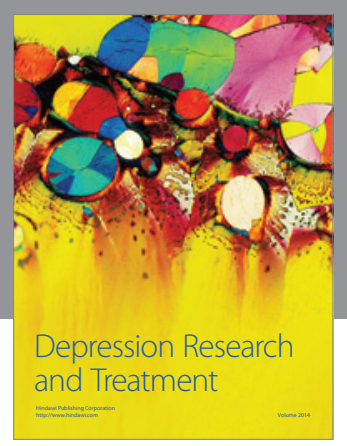
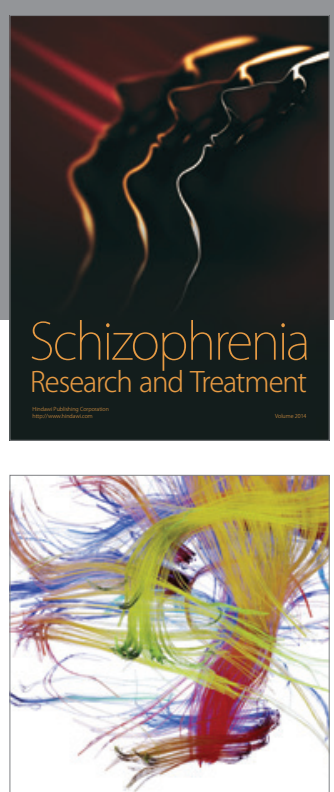

Brain Science

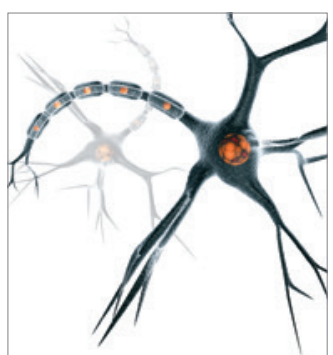

Neural Plasticity
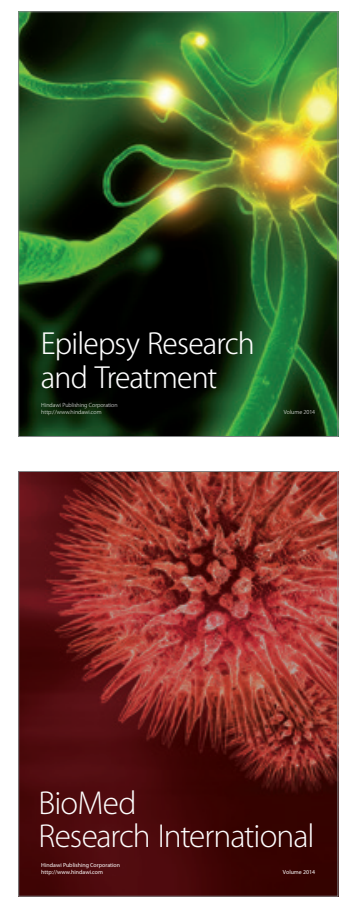

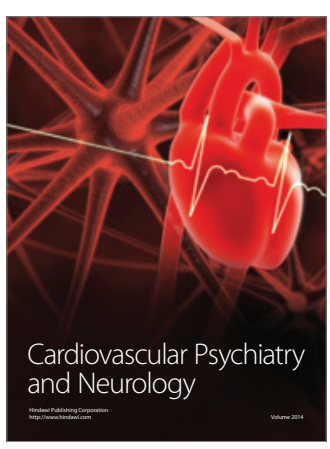

Parkinson's

Disease
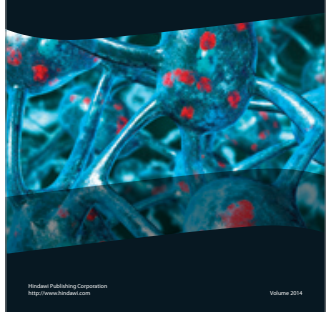